\title{
Pilotstudie : voortgezet algemeen volwassen onderwijs 1995/1996
}

Citation for published version (APA):

Allen, J. P., \& Huijgen, T. G. (2001). Pilotstudie : voortgezet algemeen volwassen onderwijs 1995/1996. Researchcentrum voor Onderwijs en Arbeidsmarkt, Faculteit der Economische Wetenschappen. ROA Working Papers No. 5 https://doi.org/10.26481/umarow.2001005

Document status and date:

Published: 01/01/2001

DOI:

10.26481/umarow.2001005

Document Version:

Publisher's PDF, also known as Version of record

\section{Please check the document version of this publication:}

- A submitted manuscript is the version of the article upon submission and before peer-review. There can be important differences between the submitted version and the official published version of record.

People interested in the research are advised to contact the author for the final version of the publication, or visit the DOI to the publisher's website.

- The final author version and the galley proof are versions of the publication after peer review.

- The final published version features the final layout of the paper including the volume, issue and page numbers.

Link to publication

\footnotetext{
General rights rights.

- You may freely distribute the URL identifying the publication in the public portal. please follow below link for the End User Agreement:

www.umlib.nl/taverne-license

Take down policy

If you believe that this document breaches copyright please contact us at:

repository@maastrichtuniversity.nl

providing details and we will investigate your claim.
}

Copyright and moral rights for the publications made accessible in the public portal are retained by the authors and/or other copyright owners and it is a condition of accessing publications that users recognise and abide by the legal requirements associated with these

- Users may download and print one copy of any publication from the public portal for the purpose of private study or research.

- You may not further distribute the material or use it for any profit-making activity or commercial gain

If the publication is distributed under the terms of Article $25 \mathrm{fa}$ of the Dutch Copyright Act, indicated by the "Taverne" license above, 


\title{
Pilotstudie
}

Voortgezet algemeen volwassenen onderwijs 1995/1996

ROA-W-2001/5

\author{
J.A. Allen en T. Huijgen
}

Researchcentrum voor Onderwijs en Arbeidsmarkt

Faculteit der Economische Wetenschappen en Bedrijfskunde Universiteit Maastricht

Maastricht, december 2001 
ISBN 90-5321-322-8

Sec01.349.doc 
Inhoud

Pagina

Voorwoord

1 Inleiding 1

2 Methodologische verantwoording 1

3 Redenen voor het volgen van een VAVO-opleiding 2

4 Algemene kenmerken van VAVO-schoolverlaters 3

5 Bestemming VAVO-schoolverlaters 6

6 Vervolgonderwijs 6

7 Arbeidsmarktsituatie 9

8 Conclusie 11

$\begin{array}{ll}\text { Appendix A Vragenlijst VAVO } 1997 & 13\end{array}$ 



\section{Voorwoord}

Dit werkdocument doet verslag van het onderzoek onder schoolverlaters van het Voortgezet Algemeen Volwassenen Onderwijs (VAVO) uit het schooljaar 1995/1996. Doel van het onderzoek was om door middel van een pilot-studie de positie van deze groep schoolverlaters in het vervolgonderwijs en op de arbeidsmarkt in kaart te brengen en daar waar mogelijk een vergelijking te maken met de reguliere gediplomeerde schoolverlaters van het AVO.

Het onderzoek is intern begeleid door dr. J. Allen en het verslag is geschreven door drs. T. Huijgen. De enquêtering van de respondenten heeft schriftelijk plaatsgevonden en is uitgevoerd door DESAN Marktonderzoek BV te Amsterdam. 



\section{Inleiding}

Het ROA voert jaarlijks enkele grootschalige schoolverlatersonderzoeken uit. Deze onderzoeken vinden plaats onder schoolverlaters van het Algemeen Voortgezet Onderwijs (AVO), het Voorbereidend Beroepsonderwijs (VBO), de Beroepsopleidende Leerweg (BOL), de Beroepsbegeleidende Leerweg (BBL), het Hoger Beroepsonderwijs (HBO) en onder afgestudeerden van het Wetenschappelijk Onderwijs (WO) ${ }^{1}$. Op basis van deze schoolverlatersonderzoeken heeft het ROA het Schoolverlatersinformatiesysteem ontwikkeld. Ter complementering van dit Schoolverlatersinformatiesysteem streeft het ROA ernaar de schoolverlatersonderzoeken over de volle breedte van het onderwijsveld uit te voeren. Mede vanwege de behoefte van de reeds deelnemende onderwijsinstellingen om meer inzicht te krijgen in de arbeidsmarktpositie en het vervolgtraject in het onderwijs van afgestudeerden van het VAVO (Voortgezet Algemeen Volwassenen Onderwijs) heeft in 1997 een pilot-studie onder deze groep schoolverlaters plaatsgevonden.

De resultaten van deze pilot-studie worden in dit werkdocument gepresenteerd. $\mathrm{Na}$ de methodologische verantwoording (paragraaf 2) wordt in paragraaf 3 nader ingegaan op de redenen voor het volgen van een VAVO-opleiding. In paragraaf 4 worden enkele algemene kenmerken van de VAVO-schoolverlaters beschreven. In de daaropvolgende paragraaf wordt de bestemming van deze schoolverlaters in kaart gebracht. Paragraaf 6 gaat in op het vervolgtraject in het onderwijs terwijl paragraaf 7 hun positie op de arbeidsmarkt beschrijft. Tenslotte volgen in de laatste paragraaf enkele conclusies.

\section{Methodologische verantwoording}

De VAVO-opleidingen maken deel uit van de Wet Educatie en Beroepsonderwijs. Naast het VAVO worden in deze wet de volgende opleidingen onderscheiden:

- Nederlands als tweede taal (NT2);

- Opleidingen gericht op breed maatschappelijk functioneren;

- Opleidingen gericht op sociale redzaamheid.

Elk van deze opleidingen levert de deelnemer een bepaalde kwalificatie op, variërend van een redzaamheid kwalificatie tot een voortgezette kwalificatie. Deze verschillende kwalificaties bieden elk een aansluitingsmogelijkheid tot het beroepsonderwijs. Het VAVOonderwijs vormt de hoogste (qua bereikbaar kwalificatieniveau) schakel in de Wet Educatie en Beroepsonderwijs. Het primaire doel van Educatie is een goede voorbereiding en aansluiting op het voortgezet en beroepsonderwijs. Bovendien gaat het bij Educatie om het leren functioneren in de samenleving. De VAVO-opleidingen zijn dan ook bedoeld voor volwassenen die een diploma of deelcertificaat MAVO, HAVO of VWO willen behalen vanwege:

1. Voor enkele recente bevindingen n.a.v. deze schoolverlatersonderzoeken zie o.a.: Schoolverlaters tussen onderwijs en arbeidsmarkt 1998, De arbeidsmarktpositie van afgestudeerden van het hoger beroepsonderwijs; HBO-Monitor 1999 en het rapport Academici op de arbeidsmarkt. 
- persoonlijke ontplooiing;

- het wegwerken van achterstanden.

De regelingen die daarvoor gelden zijn gelijk aan die in de Wet op het voortgezet onderwijs. In het schooljaar 1996/1997 namen circa 68.800 volwassenen deel aan het VAVOonderwijs.

De meting onder uitstromers van het VAVO heeft eind 1997 plaatsgevonden. Het betrof cursisten die in het schooljaar 1995/1996 een VAVO-opleiding verlaten hadden. De naam en adresgegevens van deze afgestudeerden zijn door de onderwijsinstellingen aangeleverd, er zijn 3619 personen schriftelijk benaderd. Om een hoger responspercentage te bewerkstelligen heeft onder 2594 van hen een telefonisch rappel plaatsgevonden (eerder kleinschalig onderzoek heeft aangetoond dat een laag responspercentage gebruikelijk is onder VAVO-schoolverlaters). In vergelijking met de reguliere onderzoekspopulatie van RUBS (Registratie van Uitstroom en Bestemming van Schoolverlaters) is de onderzoekspopulatie van de VAVO-meting nogal divers van samenstelling (onder andere met betrekking tot leeftijd en maatschappelijke positie). $\mathrm{Er}$ is dan ook een speciale vragenlijst voor deze meting ontwikkeld (zie appendix A). Er zijn 977 respondenten in het onderzoeksbestand terecht gekomen, hiervan zijn er bij de verdere analyses 69 afgevallen omdat ze de opleiding ongediplomeerd verlaten hadden.

\section{Redenen voor het volgen van een VAVO-opleiding}

De groep personen die ervoor kiest een VAVO-opleiding te gaan volgen kan onderverdeeld worden aan de hand van de leeftijden van de respondenten. Zo is er een onderscheid gemaakt tussen 'VAVO-jong' (respondenten van 25 jaar en jonger) en 'VAVO-oud' (respondenten ouder dan 25 jaar). Dit onderscheid is gemaakt om een relevante vergelijking te kunnen maken met de schoolverlaters uit het reguliere AVO. Om een juiste vergelijking te kunnen maken tussen beide groepen dienen ze niet alleen over dezelfde kwalificaties te beschikken maar moeten ze ook binnen dezelfde leeftijdscategorie vallen. Dit laatste is met name van belang wanneer gekeken wordt naar de arbeidsmarktpositie van beide groepen. Omdat meer dan $90 \%$ van alle AVO-schoolverlaters jonger is dan 26 jaar is besloten om bij die leeftijd de grens tussen VAVO-jongeren en VAVO-ouderen te leggen. In het vervolg van deze beschrijving van VAVO-schoolverlaters wordt (waar zinvol) een vergelijking getrokken tussen VAVO-jongeren en de reguliere AVO-schoolverlaters.

Zoals in de inleiding reeds vermeld zijn er twee groepen deelnemers. Enerzijds een groep deelnemers die een VAVO-opleiding volgt voor persoonlijke ontplooiing, anderzijds een groep die de VAVO-opleiding volgt om hiaten in hun opleiding weg te werken. Alhoewel de indeling naar leeftijd enigszins arbitrair is, blijkt deze leeftijd een goede grens te zijn om de motieven van het volgen van een VAVO-opleiding goed te kunnen scheiden. Wanneer gekeken wordt naar de motieven voor het volgen van een VAVO-opleiding blijkt er een duidelijk verschil te zijn tussen beide leeftijdsgroepen (zie tabel 3.1). 
Hier blijkt dat er één groep (overwegend jongeren) de VAVO-opleiding kiest omdat ze (enkele) kwalificaties missen voor een vervolgopleiding. Het ontbreken van deze kwalificaties kan veroorzaakt zijn doordat de scholieren een andere opleiding ongediplomeerd verlaten hebben of omdat ze bepaalde in de vervolgopleiding vereiste vakken niet hebben gevolgd. Een VAVO-opleiding biedt deze groep scholieren uitkomst. Een andere groep (overwegend ouderen) volgt een VAVO-opleiding voornamelijk uit persoonlijke interesse. De grote meerderheid van deze laatste groep volgt de opleiding dus niet als vooropleiding voor een gewenste vervolgopleiding of om een sterkere positie op de arbeidsmarkt te bemachtigen.

Tabel 3.1

Redenen om een VAVO-opleiding te gaan volgen ${ }^{2}$

$\begin{array}{ccc}\operatorname{VAVO}(25-) & \text { VAVO }(25+) & \text { VAVO totaal } \\ \% & \% & \%\end{array}$

Reden:

Vorige opleiding voortijdig afgebroken

Aanvulling vakkenpakket

Vereiste voor vervolgopleiding

Wens werkgever

Persoonlijke ontwikkeling

Persoonlijke interesse

Verhuizing

Privé-omstandigheden

Op de vrije school kon ik geen examen doen

Andere reden

$\begin{array}{rrr}30 & 7 & 21 \\ 22 & 13 & 18 \\ 40 & 13 & 29 \\ 1 & 3 & 2 \\ 18 & 81 & 43 \\ 7 & 22 & 13 \\ 1 & 1 & 1 \\ 7 & 4 & 6 \\ 13 & 0 & 8 \\ 16 & 10 & 14\end{array}$

\section{Algemene kenmerken van VAVO-schoolverlaters}

Tabel 4.1 laat de verdeling van de respondenten over de drie opleidingsniveaus zien. De oudere respondenten hebben voornamelijk een MAVO of HAVO-opleiding gevolgd terwijl de jongeren meestal een HAVO of VWO-opleiding verlaten hebben.

Tabel 4.1

Gevolgde opleiding van VAVO-schoolverlaters in steekproef

\begin{tabular}{lcc} 
& $\begin{array}{c}\text { VAVO (25-) } \\
N=494 \\
\%\end{array}$ & $\begin{array}{c}\text { VAVO (25+) } \\
\text { N }=329 \\
\%\end{array}$ \\
& & \\
\hline MAVO & 14 & 51 \\
HAVO & 46 & 32 \\
VWO & 41 & 18 \\
\end{tabular}

2. Respondenten hadden de mogelijkheid om meerdere redenen te noemen. 
Dat beide groepen respondenten duidelijk verschillen blijkt uit tabel 4.2. Het merendeel (78\%) van de VAVO-jongeren heeft de dagopleiding gevolgd, VAVO-ouderen hebben voornamelijk avondonderwijs gevolgd (71\%). De jongere groep heeft ook vaker een volledig diploma van de verlaten opleiding behaald dan de ouderen hetgeen samenhangt met de redenen die zij hebben voor het volgen van volwassenenonderwijs. Jongeren hebben het diploma vaak nodig voor verder te komen op de arbeidsmarkt terwijl ouderen de opleiding meer voor persoonlijke ontwikkeling en uit interesse volgen en derhalve niet het volledige diploma nodig hebben (zie ook tabel 3.1).

Tabel 4.2

Dag-/avondopleiding gevolgd en diplomabezit VAVO-schoolverlaters

\begin{tabular}{lccc}
\hline & $\begin{array}{c}\text { VAVO (25-) } \\
\%\end{array}$ & $\begin{array}{c}\text { VAVO } \\
\%\end{array}$ & $\begin{array}{c}\text { VAVO Totaal } \\
\%\end{array}$ \\
\hline $\begin{array}{l}\text { Dag-avondopleiding: } \\
\text { Dagopleiding }\end{array}$ & 78 & 29 & 59 \\
Avondopleiding & 22 & 71 & 42 \\
$\begin{array}{l}\text { Diplomabezit: } \\
\text { Volledig diploma } \\
\text { Deelcertificaat }\end{array}$ & 74 & 53 & 65 \\
& 27 & 47 & 35 \\
\hline
\end{tabular}

De volgende tabel laat zien welke vooropleidingen de VAVO-schoolverlaters gediplomeerd hebben verlaten. De VAVO-ouderen zijn vaker in het bezit van een diploma dan de VAVOjongeren. $22 \%$ van de ouderen heeft geen diploma behaald of geen vooropleiding gehad tegenover $54 \%$ van de jongeren. Bij de jongeren heeft men vaker een HAVO-diploma hetgeen ook verklaart waarom ze meer het VAVO-VWO gevolgd hebben dan de ouderen die voornamelijk de VAVO-MAVO doorlopen hebben (zie ook tabel 4.1). De ouderen blijken vaker in het bezit te zijn van een LBO/VBO dan wel (kort) MBO-diploma. Er is een klein aantal VAVO-schoolverlaters dat aangeeft een VWO-diploma te hebben behaald alvorens ze aan de VAVO-opleiding zijn begonnen. Dit zijn voor het overgrote deel VAVO-jongeren die na de VAVO weer een vervolgopleiding zijn gaan volgen. Als reden voor het volgen van de VAVO-opleiding werd door deze groep voornamelijk aangegeven dat dit nodig was voor de vervolgopleiding en/of dat dit als aanvulling op het vakkenpakket was.

In tabel 4.4 staan enkele persoonskenmerken van de VAVO-schoolverlaters. De VAVOjongeren zijn gemiddeld 21 jaar op het moment van enquête. AVO-schoolverlaters zijn gemiddeld genomen 3 jaar jonger. Wat betreft het geslacht is er weinig verschil tussen VAVO-jongeren en AVO-schoolverlaters. Wel zijn er bij de jonge VAVO-schoolverlaters 3\% meer allochtonen dan bij de AVO'ers. Tussen de VAVO-ouderen en de VAVO-jongeren zijn er grotere verschillen. Niet alleen zijn de VAVO-ouderen uiteraard veel ouder dan de jongeren, ook blijken VAVO-ouderen veel vaker vrouwen te zijn dan bij VAVO-jongeren het geval is. 
Tabel 4.3

Vooropleiding van VAVO-schoolverlaters

\begin{tabular}{|c|c|c|c|}
\hline & $\begin{array}{c}\operatorname{VAVO}(25-) \\
\%\end{array}$ & $\begin{array}{c}\text { VAVO }(25+) \\
\%\end{array}$ & $\underset{\%}{\text { VAVO Totaal }}$ \\
\hline Geen vooropleiding/diploma & 54 & 22 & 42 \\
\hline MAVO & 12 & 18 & 14 \\
\hline HAVO & 15 & 5 & 11 \\
\hline VWO & 5 & 1 & 4 \\
\hline LBO/VBO & 2 & 17 & 8 \\
\hline Leerlingwezen & 0 & 5 & 2 \\
\hline (kort)MBO & 4 & 12 & 7 \\
\hline Anders & 8 & 20 & 12 \\
\hline
\end{tabular}

Tabel 4.4

Persoonskenmerken van (V)AVO-schoolverlaters

\begin{tabular}{lrrr} 
& VAVO (25-) & AVO & VAVO (25+) \\
\hline Leeftijd & 21 & 18 & 43 \\
Geslacht: man & 46 & 45 & 22 \\
Etniciteit: allochtoon & 6 & 3 & 4 \\
\hline
\end{tabular}

Het verschil tussen oudere en jongere VAVO-schoolverlaters blijkt ook uit de maatschappelijke positie die men had tijdens de opleiding. Driekwart van de jongere VAVOschoolverlaters heeft ten tijde van de VAVO-opleiding geen betaalde functie. Van de oudere VAVO-schoolverlaters heeft iets meer dan de helft een betaalde functie. Met name oudere mannen hadden op het moment dat ze de opleiding volgden een betaalde functie. Ook hieruit blijkt dat met name de jongere VAVO-schoolverlaters deze opleiding gebruiken om hun arbeidsmarktpositie te verbeteren.

Tabel 4.5

Maatschappelijke positie ten tijde van opleiding

$$
\begin{gathered}
\text { VAVO (25-) } \\
\text { totaal } \\
\%
\end{gathered}
$$

VAVO (25+)

totaal

$\%$ 


\section{Bestemming VAVO-schoolverlaters}

De respondenten is gevraagd aan te geven welke bezigheid het beste bij hun situatie past op het moment van enquêteren. Schoolverlaters van het AVO stromen meestal door naar het vervolgonderwijs, zoals blijkt uit tabel 5.1. VAVO-jongeren stromen ook voornamelijk door naar het vervolgonderwijs maar toch duidelijk minder dan AVO-schoolverlaters. Vooral VAVO-jongeren met een MAVO-opleiding stromen veel minder vaak door naar het vervolgonderwijs dan hun AVO-MAVO tegenhangers. VAVO-schoolverlaters kiezen er juist vaker voor om na afronding van deze opleiding de arbeidsmarkt te betreden. Het merendeel van de VAVO-ouderen heeft na afloop van de opleiding een betaalde functie. Het verschil tussen de drie opleidingssectoren is gering. Het percentage oudere VAVO-schoolverlaters dat zich na afloop van de VAVO-opleiding als betaald werkend beschouwt, is vergelijkbaar met het percentage oudere VAVO-schoolverlaters dat tijdens de VAVO-opleiding al een betaalde functie had. Blijkbaar heeft het afronden van de VAVO-opleiding door ouderen geen verstrekkende consequenties voor hun maatschappelijke positie.

Tabel 5.1

Maatschappelijke positie VAVO-schoolverlaters, naar opleidingssector

\begin{tabular}{|c|c|c|c|c|c|c|c|c|c|}
\hline & \multicolumn{3}{|c|}{ VAVO (25-) } & \multicolumn{3}{|c|}{ AVO } & \multicolumn{3}{|c|}{ VAVO $(25+)$} \\
\hline & $\begin{array}{c}\text { MAVO } \\
\%\end{array}$ & $\begin{array}{c}\text { HAVO } \\
\%\end{array}$ & $\begin{array}{c}\text { VWO } \\
\%\end{array}$ & $\begin{array}{c}\text { MAVO } \\
\%\end{array}$ & $\begin{array}{c}\text { HAVO } \\
\%\end{array}$ & $\begin{array}{c}\text { VWO } \\
\%\end{array}$ & $\begin{array}{c}\text { MAVO } \\
\%\end{array}$ & $\begin{array}{c}\text { HAVO } \\
\%\end{array}$ & $\begin{array}{c}\text { VWO } \\
\%\end{array}$ \\
\hline BBL & 3 & 2 & 1 & 6 & 4 & 1 & 1 & 0 & 0 \\
\hline Betaald werk & 37 & 23 & 11 & 9 & 9 & 4 & 59 & 60 & 55 \\
\hline Student & 59 & 75 & 87 & 84 & 86 & 95 & 7 & 15 & 15 \\
\hline Werkloos & 2 & 0 & 2 & 0 & 0 & 0 & 12 & 8 & 0 \\
\hline Anders & 0 & 0 & 0 & 1 & 0 & 0 & 21 & 16 & 30 \\
\hline
\end{tabular}

\section{Vervolgonderwijs}

Van de 906 respondenten in de steekproef hebben er 563 aangegeven doorgestroomd te zijn naar een vervolgopleiding, dit is $62 \%$. Bij de VAVO-jongeren stroomt gemiddeld $83 \%$ door naar het vervolgonderwijs, bij de VAVO-ouderen is dit $39 \%$. De doorstroom van de reguliere AVO-schoolverlaters naar het vervolgonderwijs is $11 \%$ hoger dan bij de jongeren uit het VAVO onderwijs. Van deze groep gaat namelijk in totaal zo'n 94\% naar een vervolgopleiding. Behalve dat de VAVO-schoolverlaters minder vaak aan een vervolgopleiding beginnen is de doorstroom naar het soort vervolgonderwijs van VAVOjongeren enigzins vergelijkbaar met de doorstroom naar het soort vervolgonderwijs van AVO-schoolverlaters (zie tabel 6.1). VAVO-MAVO schoolverlaters vormen hierop een uitzondering. Van de reguliere MAVO schoolverlaters stroomt $77 \%$ door naar BOL niveau $3 / 4$, terwijl dit voor maar 53\% van de VAVO-MAVO-jongeren geldt. VAVO-MAVO-jongeren stromen juist vaker door naar een AVO-opleiding (HAVO). Ook kiezen ze iets vaker voor 
een BOL niveau 1/2-vervolgopleiding dan AVO-schoolverlaters. Van de oudere VAVOschoolverlaters die een vervolgopleiding gaan volgen, stroomt de meerderheid door naar het AVO.

Tabel 6.1

Vervolgonderwijs

\begin{tabular}{|c|c|c|c|c|c|c|c|c|c|}
\hline & \multicolumn{3}{|c|}{ VAVO (25-) } & \multicolumn{3}{|c|}{ AVO } & \multicolumn{3}{|c|}{ VAVO (25+) } \\
\hline & $\begin{array}{c}\text { MAVO } \\
\%\end{array}$ & $\begin{array}{c}\text { HAVO } \\
\%\end{array}$ & $\begin{array}{c}\text { VWO } \\
\%\end{array}$ & $\begin{array}{c}\text { MAVO } \\
\%\end{array}$ & $\begin{array}{c}\text { HAVO } \\
\%\end{array}$ & $\begin{array}{c}\text { VWO } \\
\%\end{array}$ & $\begin{array}{c}\text { MAVO } \\
\%\end{array}$ & $\begin{array}{c}\text { HAVO } \\
\%\end{array}$ & $\begin{array}{c}\text { VWO } \\
\%\end{array}$ \\
\hline $\begin{array}{l}\text { Geen vervolg- } \\
\text { opleiding }\end{array}$ & 32 & 18 & 11 & 6 & 8 & 4 & 66 & 57 & 55 \\
\hline $\begin{array}{l}\text { Wel vervolg- } \\
\text { opleiding }\end{array}$ & 68 & 82 & 89 & 94 & 92 & 96 & 34 & 43 & 45 \\
\hline $\begin{array}{l}\text { Waarvan: } \\
\text { (V)AVO } \\
\text { VBO } \\
\text { BBL } \\
\text { BO } 1 / 2 \\
\text { BO } 3 / 4 \\
\text { HBO } \\
\text { WO }\end{array}$ & $\begin{array}{r}26 \\
0 \\
4 \\
13 \\
53 \\
4 \\
0\end{array}$ & $\begin{array}{r}10 \\
0 \\
4 \\
2 \\
14 \\
67 \\
4\end{array}$ & $\begin{array}{r}4 \\
0 \\
0 \\
0 \\
4 \\
39 \\
53\end{array}$ & $\begin{array}{r}12 \\
0 \\
5 \\
5 \\
77 \\
0 \\
0\end{array}$ & $\begin{array}{r}6 \\
0 \\
4 \\
2 \\
16 \\
72 \\
0\end{array}$ & $\begin{array}{r}1 \\
0 \\
0 \\
0 \\
1 \\
38 \\
59\end{array}$ & $\begin{array}{r}58 \\
14 \\
7 \\
2 \\
16 \\
2 \\
2\end{array}$ & $\begin{array}{r}60 \\
2 \\
7 \\
4 \\
2 \\
20 \\
4\end{array}$ & $\begin{array}{r}43 \\
0 \\
8 \\
0 \\
4 \\
27 \\
19\end{array}$ \\
\hline
\end{tabular}

Respondenten is gevraagd een waardeoordeel te geven over de aansluiting tussen de, eventueel, door hun gevolgde vervolgopleiding en de gevolgde VAVO-opleiding (zie tabel $6.2)$.

Tabel 6.2

Aansluiting gevolgde opleiding met vervolgopleiding naar leeftijd, gevolgde opleiding en gevolgde vervolgopleiding

\begin{tabular}{|c|c|c|c|c|c|c|c|c|c|c|c|c|}
\hline & \multicolumn{4}{|c|}{ VAVO (25-) } & \multicolumn{4}{|c|}{ AVO } & \multicolumn{4}{|c|}{ VAVO (25+) } \\
\hline & $\begin{array}{c}\text { (v)avo } \\
\%\end{array}$ & $\begin{array}{c}\text { bol } \\
\%\end{array}$ & $\begin{array}{c}\text { hbo } \\
\%\end{array}$ & $\begin{array}{l}\text { wo } \\
\%\end{array}$ & $\begin{array}{c}\text { (v)avo } \\
\%\end{array}$ & $\begin{array}{c}\text { bol } \\
\%\end{array}$ & $\begin{array}{c}\text { hbo } \\
\%\end{array}$ & $\begin{array}{l}\text { wo } \\
\%\end{array}$ & $\begin{array}{c}\text { (v)avo } \\
\%\end{array}$ & $\begin{array}{c}\text { bol } \\
\%\end{array}$ & $\begin{array}{c}\text { hbo } \\
\%\end{array}$ & $\begin{array}{l}\text { wo } \\
\%\end{array}$ \\
\hline Goed & 70 & 51 & 43 & 35 & 44 & 34 & 44 & 45 & 68 & 45 & 47 & - \\
\hline Voldoende & 22 & 34 & 39 & 45 & 34 & 46 & 34 & 36 & 18 & 36 & 41 & - \\
\hline Matig & 5 & 9 & 15 & 12 & 20 & 15 & 18 & 15 & 9 & 10 & 12 & - \\
\hline Slecht & 3 & 6 & 3 & 8 & 2 & 6 & 4 & 5 & 5 & 10 & 0 & - \\
\hline
\end{tabular}

$-=$ te weinig waarnemingen

Wanneer er gedifferentieerd wordt naar vervolgopleiding blijkt dat zowel de VAVO-jongeren $(70 \%)$ als de VAVO-ouderen (68\%) een redelijk positief oordeel hebben over de aansluiting 
tussen de gevolgde opleiding en de AVO-vervolgopleiding. De reguliere AVO-scholieren die binnen het AVO doorstromen zijn hier minder positief over (44\%). Eenzelfde beeld geldt voor schoolverlaters die een vervolgopleiding in de BOL zijn gaan volgen. Ook hier zijn de AVO schoolverlaters het minst tevreden. Voor de doorstomers naar het HBO geldt dat er relatief weinig verschil in oordeel is tussen de VAVO-jongeren, -ouderen en de reguliere AVOschoolverlaters. Wel vinden de AVO-schoolverlaters het vaakst $(22 \%)$ dat de aansluiting tussen de gevolgde AVO-opleiding en de HBO-opleiding matig tot slecht was. $35 \%$ van de VAVO-jongeren vindt de aansluiting met de WO-vervolgopleiding goed en $45 \%$ vind dit voldoende voldoende. Bij de AVO-schoolverlaters is deze verdeling tussen goed en voldoende vrijwel precies andersom.

Bijna 14\% van de jongere VAVO-schoolverlaters die begonnen zijn aan een vervolgopleiding hebben op het moment van enquête deze vervolgopleiding ongediplomeerd verlaten. Bij de ouderen is dit 17\%, bij de reguliere AVO-schoolverlaters houdt $12 \%$ op met de vervolgopleiding. De belangrijkste redenen van VAVO-jongeren voor het voortijdig verlaten van de vervolgopleiding zijn meestal van persoonlijke aard. Een gebrek aan motivatie, en weinig zelfdiscipline worden vaak genoemd als argument op te stoppen met de vervolgopleiding. Ook wordt de opleiding vaak oninteressant gevonden. Deze redenen worden door VAVO-schoolverlaters iets vaker genoemd dat door andere schoolverlaters van het AVO, zoals de rechterkolom van tabel 6.3 laat zien. AVO-schoolverlaters die stoppen met de vervolgopleiding lijken vaker moeite te hebben met het tempo en de moeilijkheidsgraad van de vervolgopleiding. Bij de VAVO-ouderen is het met name om persoonlijke redenen dat men de vervolgopleiding niet afmaakt.

Tabel 6.3

Redenen voor uitval, jongeren ${ }^{3}$

\begin{tabular}{lcc}
\hline & $\begin{array}{c}\text { VAVO (25-) } \\
\%\end{array}$ & $\begin{array}{c}\text { AVO } \\
\%\end{array}$ \\
& & \\
Motivatie & 40 & 36 \\
Zelfdiscipline & 12 & 17 \\
Gebrekkige aansluiting & 2 & 7 \\
Te moeilijk & 8 & 19 \\
Tempo te hoog & 8 & 15 \\
Oninteressant & 23 & 33 \\
Verkeerde info & 18 & 13 \\
Andere opleiding & 43 & 40 \\
Werken & 12 & 5 \\
Persoonlijke redenen & 7 & 11 \\
\hline
\end{tabular}

Een deel van de studenten heeft tijdens de VAVO-opleiding studiekeuzebegeleiding gehad. Gezien de redenen die men heeft voor het volgen van een VAVO-opleiding (zie paragraaf 3 ) kan deze begeleiding met name voor de VAVO-jongeren van belang zijn. De respondenten is gevraagd of er voldoende aandacht aan studiekeuzebegeleidng besteed is, wat ze

3. Respondenten hadden de mogelijkheid meerdere redenen te noemen. 
vonden van de kwaliteit van het begeleidingsmateriaal en aan welke punten de dekaan meer aandacht had moeten besteden. In tabel 6.4 staan enkele gegevens over de meningen die de VAVO-jongeren achteraf over de ontvangen studiebegeleiding hadden. Meer dan een kwart van de VAVO-jongeren vindt dat de aandacht die er besteed werd aan studiekeuzebegeleiding tijdens de opleiding niet voldoende was. De oudere VAVO-schoolverlaters waren hierover duidelijk positiever. Gemiddeld $28 \%$ van de VAVO-jongeren vindt dat de kwaliteit van het begeleidingsmateriaal matig tot slecht was, bij de MAVO schoolverlaters was dit zelfs $39 \%$. De jongeren vinden daarnaast dat de dekaan met name meer aandacht moet besteden aan de inhoud van de vervolgopleidingen en de individuele mogelijkheden en vaardigheden die men heeft met betrekking tot de vervolgopleiding. De VAVO-ouderen waren op alle punten minder ontevreden.

Tabel 6.4

Oordeel van VAVO-jongeren over studiekeuzebegeleiding en dekaan

VAVO (25-)

\begin{tabular}{ccc}
\hline MAVO & HAVO & VWO \\
$\%$ & $\%$ & $\%$ \\
& & \\
\hline
\end{tabular}

Onvoldoende aandacht voor studiekeuzebegeleiding

Kwaliteit begeleidingsmateriaal matig/slecht

28

39

Dekaan moet meer aandacht besteden aan: ${ }^{4}$

- Inhoud van vervolgopleidingen

- Zwaarte van vervolgopleidingen

- Kans op werk na vervolgopleiding

- Beroepsmogelijkheden van vervolgopleiding

- Eigen mogelijkheden en vaardigheden

M.b.t. vervolgopleiding

$\begin{array}{lll}28 & 30 & 30 \\ 39 & 26 & 27\end{array}$

\section{Arbeidsmarktsituatie}

VAVO-schoolverlaters die de gevolgde opleiding gebruiken om hun arbeidsmarktpositie te verbeteren bevinden zich voornamelijk onder de jongere schoolverlaters. Oudere VAVO'ers gebruiken de opleiding meestal voor zelfontplooiing. Dit blijkt ook uit de arbeidsmarktgegevens van deze laatste groep (zie de tabellen 7.1 tot en met 7.4). Het blijkt dat VAVO-jongeren die de arbeidsmarkt betreden aanzienlijk vaker werkloos zijn dan AVOschoolverlaters (zie tabel 7.1). Vooral VAVO-MAVO en VAVO-VWO-jongeren vinden vaak geen baan.

De reguliere AVO-MAVO en AVO HAVO-jongeren werken minder vaak in loondienst dan AVO-schoolverlaters met een zelfde opleidingsachtergrond (zie tabel 7.2). AVO VWOjongeren zijn daarentegen juist vaker in loondienst bij hun werkgever dan VAVO VWO-

4. Respondenten konden meerdere items noemen. 
schoolverlaters. De VAVO-ouderen werken meestal al veel langer (werkende ouderen hebben hun huidige functie bijvoorbeeld al gemiddeld 8,5 jaar, bij de jongeren is dit gemiddeld1,4 jaar) en zijn veel vaker in loondienst bij een werkgever.

Tabel 7.1

Werkloosheid

\begin{tabular}{lccc}
\hline & $\begin{array}{c}\text { VAVO (25-) } \\
\%\end{array}$ & $\begin{array}{c}\text { AVO } \\
\%\end{array}$ & $\begin{array}{c}\text { VAVO }(25+) \\
\%\end{array}$ \\
\hline MAVO & 14 & 8 & 18 \\
HAVO & 6 & 4 & 8 \\
VWO & 18 & 3 & 10 \\
\hline
\end{tabular}

Tabel 7.2

Loondienst

\begin{tabular}{lccc}
\hline & $\begin{array}{c}\text { VAVO } \\
\%\end{array}$ & $\begin{array}{c}\text { AVO } \\
\%\end{array}$ & $\begin{array}{c}\text { VAVO (25+) } \\
\%\end{array}$ \\
\hline MAVO & 48 & 40 & 92 \\
HAVO & 66 & 50 & 89 \\
VWO & 56 & 73 & 85 \\
\hline
\end{tabular}

Een belangrijk verschil tussen VAVO-jongeren en AVO-schoolverlaters is de beloning (tabel 7.3). VAVO-schoolverlaters verdienen over de gehele linie meer dan AVO-schoolverlaters. Een belangrijke reden hiervoor vormt het leeftijdsverschil tussen VAVO-schoolverlaters en AVO-schoolverlaters, zoals al bleek uit tabel 4.4. Zeker voor deze leeftijdscategorieën geldt dat de beloning positief afhankelijk is van de leeftijd (wettelijke bepalingen omtrent het jeugdloon zijn gekoppeld aan leeftijd). Deze beloningsverschillen kunnen wellicht ook voor een deel de hoge werkloosheid onder VAVO-jongeren verklaren. Aangezien er geen qua kwalificaties geen verschil bestaat tussen een VAVO-opleiding en een AVO-opleiding, beslissen werkgevers wellicht eerder een 'goedkopere' AVO-schoolverlater aan te nemen dan een 'duurdere' VAVO-schoolverlater. Ook uit de hoge uurlonen van de VAVO-ouderen blijkt dat het een hele andere groep is dan de VAVO-jongeren en de reguliere AVO-schoolverlaters.

Tabel 7.3

Bruto uurloon (in guldens)

\begin{tabular}{lccc}
\hline & $\begin{array}{c}\text { VAVO }(25-) \\
\%\end{array}$ & $\begin{array}{c}\text { AVO } \\
\%\end{array}$ & $\begin{array}{c}\text { VAVO }(25+) \\
\%\end{array}$ \\
\hline MAVO & 13,10 & 10,04 & 25,30 \\
HAVO & 16,00 & 10,35 & 25,60 \\
VWO & 13,10 & 11,77 & 24,90 \\
\hline
\end{tabular}


Tabel 7.4 tenslotte laat zien dat er geen structurele verschillen bestaan tussen de VAVO-ers en AVO-ers voorzover het het niveau van de baan betreft. Voor de VAVO-ouderen geldt dat het overgrote deel een baan heeft die past bij hun opleidingsniveau.

Tabel 7.4

Baan op minstens op eigen niveau

\begin{tabular}{lccc}
\hline & $\begin{array}{c}\text { VAVO } \\
\%\end{array}$ & $\begin{array}{c}\text { AVO } \\
\%\end{array}$ & $\begin{array}{c}\text { VAVO }(25+) \\
\%\end{array}$ \\
\hline MAVO & 91 & 85 & 91 \\
HAVO & 42 & 46 & 77 \\
VWO & 61 & 84 & 86 \\
\hline
\end{tabular}

\section{Conclusie}

Eind 1997 heeft een meting plaatsgevonden onder cursisten die in het schooljaar 1995/1996 een VAVO-opleiding hebben afgerond. Op basis van de reden waarom men de VAVOopleiding is gaan volgen is de populatie ten behoeve van verdere analyse verdeeld in twee groepen:

- 25 jaar en jonger (deze groep heeft de opleiding met name gevolgd om een (verdere) kwalificatie te behalen)

- 26 jaar of ouder (deze groep heeft de opleiding met name gevolgd voor verdere persoonlijke ontplooiing).

Het verschil tussen beide groepen zit met name in het aandeel werkenden. Bij de VAVOouderen heeft iets meer dan de helft een betaalde functie, bij de jongeren is dit een kwart. De groep VAVO-ouderen bestaat daarnaast uit een aanzienlijk hoger aandeel vrouwen. De VAVO-jongeren benaderen wat betreft algemene kenmerken de reguliere AVOschoolverlaters. VAVO-jongeren stromen minder vaak dan hun AVO-collega's door naar een vervolgopleiding, daarentegen komen ze vaker in betaalde functies terecht. Dit laatste geldt in nog sterkere mate voor de VAVO-ouderen. Het overgrote deel van de respondenten (zowel bij de VAVO-jongeren als bij VAVO-ouderen was dit meer dan driekwart van de respondenten) die doorstromen naar het vervolgonderwijs vindt de aansluiting tussen de gevolgde VAVO-opleiding en de vervolgopleiding goed of voldoende.

Een vergelijking tussen de VAVO-jongeren en de reguliere AVO-schoolverlater leert dat de VAVO-ers vaker werkloos zijn en vaker in loondienst werken. Het blijkt daarnaast dat de werkende VAVO-jongere een hoger bruto-uurloon heeft dan de AVO-schoolverlaters hetgeen waarschijnlijk veroorzaakt wordt door de gemiddeld hogere leeftijd van de VAVOstudenten. Het lijkt er op dat de reguliere AVO schoolverlater een voordeel heeft ten opzichte van zijn VAVO-collega door het feit dat deze VAVO-cursist (met dezelfde kwalifiatie) relatief duur is voor werkgevers. 



\section{Appendix A Vragenlijst VAVO 1997}

Toelichting

- Kruis het hokje aan dat voor u van toepassing is.

- Kruis steeds maar één antwoord aan, tenzij uitdrukkelijk anders is aangegeven.

- Antwoorden op open vragen op de aangegeven stippellijntjes noteren.

- $\quad$ Let goed op naar welke vraag u wordt doorverwezen. Een aantal vragen hoeft u misschien niet in te vullen.

Algemeen

1. Geslacht. 1 man

2 vrouw

2. Wat is uw leeftijd?

jaar

3. Tot welke bevolkingsgroep rekent u zichzelf? 1 Nederlandse

(bv. Surinaamse, Turkse, Marokkaanse) 2 andere,

namelijk:

4. Welke taal wordt bij $u$ thuis gesproken?

1 Nederlands

2 anders, namelijk:

\section{Opleiding schooljaar 1995/1996}

5a Hiernaast staat de opleiding die $u$ in het schooljaar 1995/1996 heeft verlaten. Is dat juist?

1 ja

2 nee,ik heb in dat jaar een andere opleiding verlaten, namelijk:

3 nee, ik heb in dat jaar geen opleiding verlaten.

5b Heeft $\mathrm{u}$ de dag- of avondopleiding gevolgd? 1 dagopleiding

2 avondopleiding

5c Waarom bent $u$ destijds deze opleiding gaan 1 volgen?

Meerdere antwoorden mogelijk.

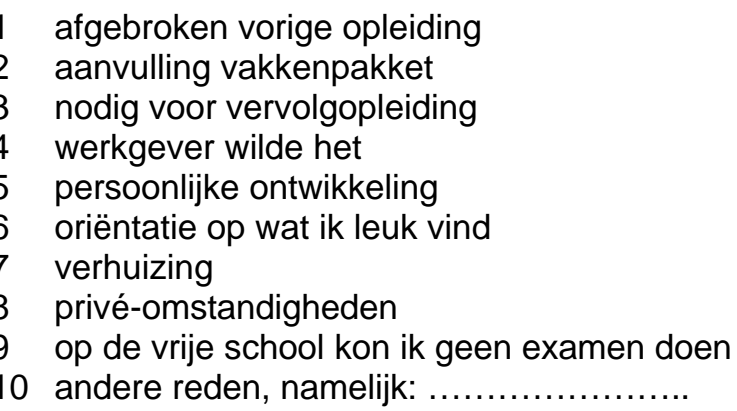

5d Volgde $u$ nog een andere opleiding of had $u$ een baan naast het volgen van deze opleiding?

a, ik had ook een baan

3 ja, ik volgde nog een andere opleiding én had ook een baan

4 nee, ik volgde alleen de VAVO-opleiding

begin maand: jaar: $19 \ldots \ldots$

klas:

einde maand: jaar: $19 \ldots \ldots$

$5 f \quad$ Wanneer heeft $u$ deze opleiding verlaten? En in welke klas?

klas: 
$5 \mathrm{~g}$ Heeft $\mathrm{u}$ van deze opleiding het diploma behaald?

1 volledig diploma alleen deelcertificaten geen diploma of deelcertificaat behaald

6 ga naar vraag $6 a$

Vraag 5 h hoeft u alléén te beantwoorden als $u$ in het schooljaar 1995/1996 een MAVO-, HAVO- of VWO-opleiding heeft verlaten.

5h Geef hiernaast op de

stippellijntjes uw eindexamenciffer aan voor al de vakken waarvoor $u$ in het schooljaar 1995/1996 examen

MAVO MAVO HAVO VWO hebt gedaan. Let op dat $u$ de cijfers bij het juiste niveau noteert.

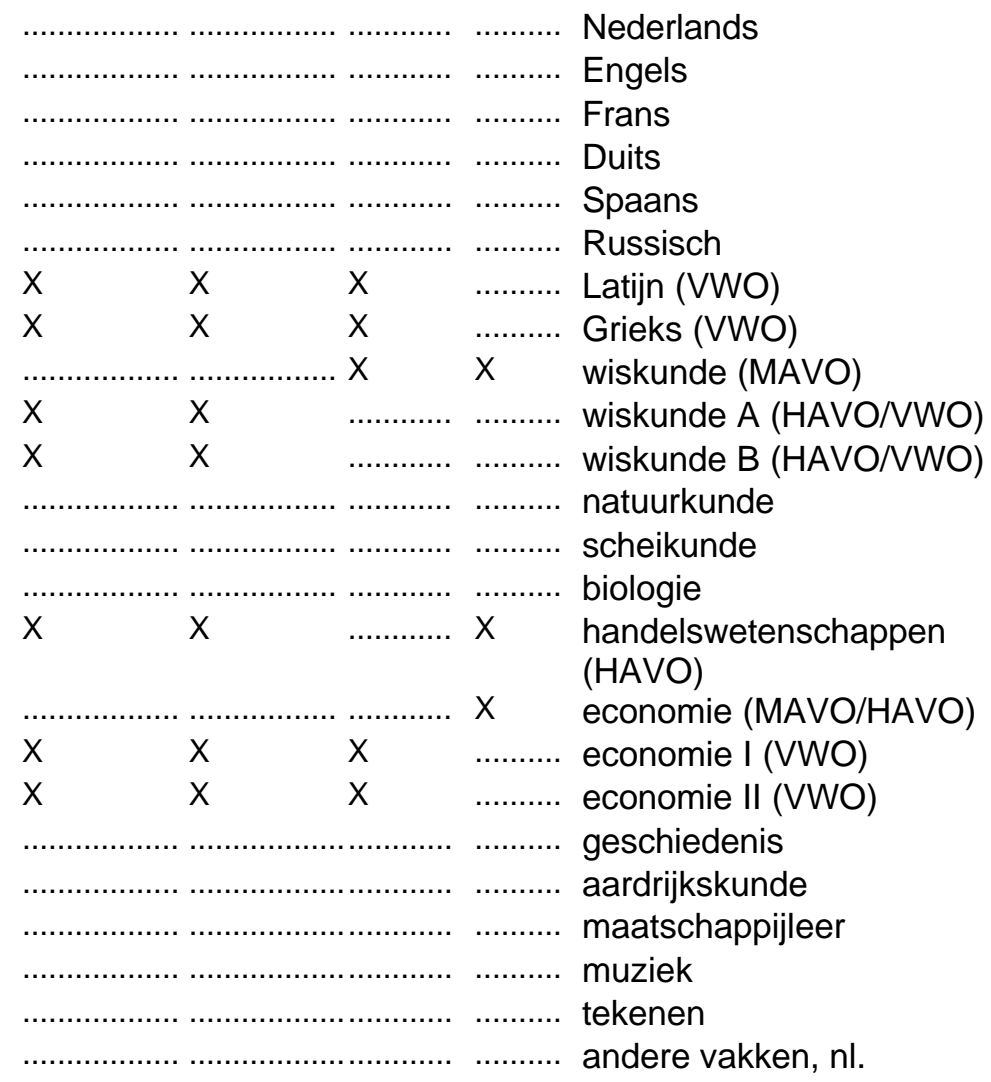


Vóóropleiding (vóór de VAVO-opleiding van schooljaar 1995/1996)

6a Welke opleiding heeft u vóór de VAVOopleiding gevolgd? Geef op de stippellijntjes 2 ook de opleidingsrichting aan. (bv. LTS bouwtechniek, KMBO horeca)

géén opleiding basisonderwijs

3 buitenlandse opleiding

4 reguliere MAVO

5 reguliere HAVO

6 reguliere VWO

7 LBO/VBO:

8 in-service of leerlingwezen:

9 kort $\mathrm{MBO} / \mathrm{KMBO}$ :

10 MBO:

11 anders, namelijk

6b Heeft $\mathrm{u}$ van deze vooropleiding het diploma 1 volledig diploma behaald?

2 alleen deelcertificaten

3 geen diploma of deelcerticifaten

\section{Studiekeuzebegeleiding achteraf bezien}

7a Was er voldoende aandacht voor studiekeuzebegeleiding?

1 ruim voldoende

2 voldoende

3 onvoldoende

7b Heeft $\mathrm{u}$ bij de VAVO-instelling gebruik 1 ja gemaakt van de studiekeuzebegeleiding? 2 nee gemaakt van de studiekeuzebegeleidi

1 goed

2 voldoende studiekeuzebegeleidingsmateriaal?

3 matig

4 slecht

7d Waaraan zouden dekanen meer aandacht moeten besteden? Meerdere antwoorden mogelijk.

1 inhoud van vervolgopleidingen

2 zwaarte van vervolgopleidingen

3 kansen op werk met vervolgopleidingen

4 beroepsmogelijkheden met vervolgopleidingen

5 mijn eigen mogelijkheden en vaardigheden voor vervolgopleidingen

\section{Vervolgopleiding (ná de VAVO-opleiding van schooljaar 1995/1996)}

8. Bent $\mathrm{u}$ na het verlaten van de opleiding van 1 ja schooljaar 1995/1996:

- een opleiding in het leerlingwezen gaan volgen òf

2 nee; ik wilde dit wel, maar ik kon geen leer-

\section{arbeidsplaats vinden}

3 nee

- $\quad$ een in-service opleiding in de verpleging of verzorging gaan volgen?

(bv. voor automonteur, schilder, restaurantkok, A-verpleegkundige of ziekenverzorgende)

9a Bent u ná het verlaten van de opleiding van 1 ja het schooljaar 1995/1996 een andere 2 nee 6 ga naar vraag $9 b$ vervolgopleiding gaan volgen? géén cursus of bedrijfsopleiding.

Heeft u ná het verlaten van de opleiding van schooljaar 1995/1996 meerdere vervolgopleidingen gevolgd, dan gaan de vragen $9 \mathrm{~b} t / \mathrm{m} 11 \mathrm{~b}$ alléén over de eerste vervolgopleiding. 
9b Wat is de officiële naam van deze vervolgopleiding? Geef schooltype en eventuele opleidingsrichting aan. (bv. VWO, MBO-bedrijfsadministratie, HBO-informatica, WO-psychologie)

9c Alleen invullen als u naar het MBO bent gegaan:

Welk soort MBO-opleiding volg(de) u?

opleidingsrichting:

schooltype:

9d Volg(de) u de voltijd- of deeltijd-variant van deze vervolgopleiding?

1 MBO kort/basisberoepsopleiding

2 MBO tussen/vakopleiding

$3 \mathrm{MBO}$ lang/vakopleiding

$4 \mathrm{MBO}$ lang/middenkaderopleiding

is dit de vervolgople

9e Is dit de vervolgopleiding die met uw vorige school was besproken? (bv. met dekaan, mentor)

1 voltijd-variant

2 deeltijd-variant

9f In welke plaats volg(de) u deze vervolgopleiding?

ja

2 nee, andere opleiding besproken

3 n.v.t., opleidingskeuze niet met vorige school besproken

plaats opleiding:

9g Hoe vindt $\mathrm{u}$ de aansluiting tussen uw 1 goed opleiding van schooljaar 1995/1996 en deze 2 voldoende vervolgopleiding?

3 matig

4 slecht

9h Volgt $\mathrm{u}$ deze vervolgopleiding nog steeds?

1 ja

6 ga naar vraag $10 a$

2 nee, diploma, getuigschrift of deelcertificaat behaald

6 ga naar vraag $10 a$

3 nee, vervolgopleiding voortijdig verlaten

6 ga naar vraag $11 a$

10 a Komt deze vervolgopleiding overeen met hetgeen op de vorige school is verteld, wat betreft de hiernaast genoemde punten?

$\begin{array}{lll}\text { ja, komt } & \text { nee, komt } & \text { n.v.t. niet } \\ \text { overeen } & \text { niet overeen } & \text { besproken } \\ 1 & 2 & 3 \\ 1 & 2 & 3 \\ 1 & 2 & 3 \\ 1 & 2 & 3 \\ 1 & 2 & 3\end{array}$

10b Zou u deze vervolgopleiding, achteraf 1 ja bezien, opnieuw kiezen? $\quad 2$ nee

6 ga naar vraag 12

2 nee 6 ga naar vraag 12

11a Waarom bent u met deze vervolgopleiding 1 ik was onvoldoende gemotiveerd gestopt?

Meerdere antwoorden mogelijk

2 ik had te weinig zelfdiscipline

3 vakkenpakket vooropleiding sloot niet aan

4 ik vond de opleiding te moeilijk

5 het tempo lag te hoog

6 de lessen waren niet interessant

7 verkeerde informatie over opleiding gehad

8 ik wilde achteraf toch liever een andere opleiding gaan volgen

9 ik wilde liever gaan werken

10 persoonlijke redenen (ziekte, verhuizing e.d.)

11 andere reden, namelijk 
11b Hiernaast noemen we een aantal zaken van de vervolgopleiding die $u$ tussentijds hebt verlaten. Heeft u hiermee problemen gehad?
a. Het onderscheiden van hoofd- en bijzaken
b. De hoeveelheid zelfstudie.
c. Het plannen van de zelfstudie.

123
d. Het aantal vakken waarover de aandacht verdeeld moest worden
e. De vereiste voorkennis.
f. De hoeveelheid theorie.

vaak

soms nooit

problemen problemen problemen 
$16 \mathrm{c}$ Om welke reden kunt u niet eerder beginnen?
1 opzeggen huidige baan

2 afronden vrijwilligerswerk

3 afronden opleiding/studie

4 regelen kinderopvang

5 vakantie

6 ziekte

7 andere reden, namelijk:

$16 \mathrm{~d}$ Bent $\mathrm{u}$ als werkzoekende ingeschreven bij 1 ja het arbeidsbureau?

\section{Verwijzing}

17. Heeft $\mathrm{u}$ op dit moment:

- (ook) betaald werk (betaalde bijbanen tellen mee).

- een leer-arbeidsplaats in het kader van het leerlingwezen of in-service onderwijs.

Let op: stage buiten het leerlingwezen of in-service onderwijs telt niet mee!

1 ja, ga dan verder met vraag 18

2 nee, ga dan verder met vraag $27 a$

\section{Kenmerken huidige functie}

Indien u op dit moment meer dan één baan heeft, dan hebben de vragen18 t/m 26 alléén betrekking op de baan met de meeste arbeidsuren.

18 Wanneer bent $u$ in uw huidige baan begonnen? werkte $u$ al vóór het verlaten van de opleiding van schooljaar 1995/1996 in deze baan, tel die periode dan ook mee. maand: jaar: 19

19a Wat is de officiële naam van uw huidige functie? (bv. lasser, verkoper, automonteur, metselaar, ober, secretaresse, ziekenverzorgende)

19b Wat zijn uw voornaamste werkzaamheden?

(bv. technisch tekenen, verkopen van kleding, schilderen, bloemen telen, boekhouden)

20a In wat voor organisatie of bedrijf werkt u?

(bv. machinefabriek, garagewerkplaats, kledingwinkel, hotel, ziekenhuis)

20b Wat voor soort product of dienst levert het bedrijf of de organisatie? (bv. landbouwmachines, bouwtechnisch advies, drukwerk, medische verzorging)

21 In wat voor dienstverband werkt u?

1 leer-arbeidsovereenkomst (via leerlingwezen/in-service)

2 werk via uitzendbureau

3 loondienst bij werkgever

4 oproepkracht, 0 -uren- of min-/max contract

5 werkervaringsproject (bv. Jeugdwerkgarantieplan)

6 werk in bedrijf ouders/partner met arbeidscontract

7 werk in bedrijf ouders/partner zonder arbeidscontract

8 zelfstandige in eigen bedrijf (incl. maatschap) of free-lance

9 anders, namelijk:

6 ga naar vraag 22

6 ga naar vraag 22

6 ga naar vraag 22

6 ga naar vraag 22

6 ga naar vraag 22

6 ga naar vraag 22

6 ga naar vraag 23

6 ga naar vraag 23

6 ga naar vraag 22 
22. Wat voor aanstelling heeft $u$ ? Vul bij tijdelijk werk ook de totale duur van uw contract in.
1 tijdelijke aanstelling voor ...... maanden, zonder uitzicht op vaste baan

2 tijdelijke aanstelling voor ...... maanden, met uitzicht op vaste baan

3 vaste aanstelling of proeftijd voor vaste baan

23. Welk opleidingsniveau werd door uw werkgever voor deze functie minimaal vereist?

Welk opleidingsniveau is volgens uzelf voor deze functie minimaal vereist?

Kruis voor beide een antwoord aan.

$\begin{array}{lll}\text { door uw werkgever } & \text { volgens uzelf } & \\ 1 & 1 & \text { basisonderwijs voldoende } \\ 2 & 2 & \text { tenminste MAVO of LBO/VBO } \\ 3 & 3 & \text { tenminste HAVO, VWO } \\ 4 & 4 & \text { tenminste kort MBO/KMBO } \\ 5 & 5 & \text { tenminste MBO } \\ 6 & 6 & \text { tenminste HBO of universiteit }\end{array}$

24. Geeft $u$ in uw functie leiding aan andere personen medewerkers? Zo ja, aan hoeveel?

25. Hoeveel uur per week werkt $u$ in deze functie?

- excl. overwerk.

- excl. uren voor eventuele nevenfunctie(s).

- ga bij wisselende werkweken uit van het gemiddelde. per week: arbeidsuren

Als $u$ in het leerlingwezen zit, telt $u$ de uren op school niet mee.

26. Hoeveel verdient $u$ bruto per maand in deze functie?

- incl. stagevergoeding, toeslagen ploegendienst, fooien, provisie e.d.

- excl. overwerk, vakantiegeld, 13e maand, uitkering, (studie)beurs e.d.

- excl. inkomen voor eventuele nevenfunctie(s).

- ga bij wisselende verdiensten uit van het gemiddelde. bruto gulden per maand

Tot slot

27a Mogen uw antwoorden aan uw vroegere school worden doorgegeven? (zie ook de begeleidende brief)

1 ja, ik vind dit goed

2 nee, ik vind dit niet goed

27b In de toekomst wordt dit onderzoek misschien herhaald. Daarvoor is uw naam en adres nodig. Wilt u die hiernaast invullen?

naam:

straat + huisnr:

postcode + plaats:

Opmerkingen

Hartelijk bedankt voor het invullen!

Stuur de vragenlijst zo snel mogelijk op in de antwoordenvelop (een postzegel is niet nodig). 
